\title{
ALIH KODE DAN CAMPUR KODE PADA POLA KOMUNIKASI DOSEN UNIVERSITAS KOMPUTER INDONESIA (UNIKOM) DI APLIKASI KULIAH ONLINE UNIKOM: KAJIAN SOSIOLINGUISTIK
}

\author{
Muhammad Rayhan Bustam, Asih Prihandini, Nungki Heriyati
}

Program Studi Sastra Inggris, Fakultas Sastra, Universitas Komputer Indonesia

Email : rayhan.bustam@gmail.com

\begin{abstract}
ABSTRAK. Penelitian yang berjudul "Alih Kode dan Campur Kode pada Pola Komunikasi Dosen UNIKOM di Aplikasi Kuliah Online Unikom: Kajian Sosiolinguistik” ini bertujuan untuk mendeskripsikan jenis, bentuk, serta tujuan digunakannya alih kode dan campur kode pada ujaran yang dikemukakan oleh dosen-dosen UNIKOM di aplikasi Kuliah Online. Adapun yang menjadi subjek penelitian ini adalah bahasa yang digunakan oleh dosen-dosen UNIKOM di aplikasi Kuliah Online tersebut, sedangkan objeknya adalah alih kode dan campur kode pada ujaran yang diungkapkan dosen-dosen tersebut. Teknik pengumpulan data menggunakan purposive sampling; yakni mengumpulkan sampel data yang berisikan kasuskasus alih kode dan campur kode dengan tujuan untuk mengetahui karakteristik jenis, bentuk, dan tujuan pemakaian alih kode dan campur kode, kemudian dianalisis dengan teknik analisis deskriptif sesuai dengan konteksnya. Hasil penelitian menunjukkan 44 kasus terjadinya alih kode dan campur kode atau persentase penggunaan jenis ini mencapai 86,3\% atau setara dengan 38 kasus. Sebaliknya, jenis alih kode yang paling sedikit terjadi adalah alih kode tag; persentase penggunaannya hanya 2,3\% atau setara dengan 1 kasus. Sedangkan, jenis alih kode antarkalimat atau klausa mencapai persentase 11,4\% atau setara dengan 5 kasus. Di sisi lain penggunaan bentuk alih dan campur kode yang ditemukan adalah 11,4\% penggunaan bentuk alih dan campur kode intern atau setara dengan 5 kasus. Sedangkan, bentuk ekstern mencapai 88,6\% atau setara dengan 39 kasus. Dari aspek tujuan penggunaan alih dan campur kode, dari total 26 data terjadinya alih dan campur kode, hanya empat tujuan alih dan campur kode yang ditemukan, yakni memperhalus permintaan sebanyak 3 kasus atau setara 11,6\%, memberikan penekanan dari ungkapan sebanyak 1 kasus atau setara 3,8\%, menunjukkan hubungan yang informal atau kedekatan sebanyak 4 kasus atau setara 15,4\%, dan kebutuhan leksikal sebanyak 18 kasus atau setara 69,2\%.
\end{abstract}

Kata Kunci: alih kode, campur kode, kuliah online

Abstract. This studies entitled "Code Switching and Code mixing on the communication patterns of lectures of Indonesia Computer Universities (UNIKOM) in the online college application: A Sociolinguistic Studies". This study aims to describe the types, form, and purpose of using code switching and intervening in speech expressed by UNIKOM lectures in the online lecture application. While, the object is code switching and code mixing in the untterances expressed by the lectures. Data colection techniques use purposive sampling; that is collecting data samples containing cases of code switching and code mixing, then analyzed with descriptive analysis techniques in accordance with the context. The results of this study showed 44 cases of code mixing or the percentage of this type of use reched $86.3 \%$ or equivalent to 38 cases. On the contrary, the smallest type of code switching; the percentage of use is only 2,3\% or equivalent to 1 case. Whereas, the type of interalimic code 
Jurnal Penelitian Humano, Vol. 9 No. 1 Edisi Juni 2018

switching or clause reached a percentage of $11.4 \%$ of the use of transfer forms and interfering internal code or equivalent to 5 cases. Whereas, extreme forms reaches 88 cases. From the aspects of the purpose of the use of transfer and code mixing found, namely to refine the request as much as 3 cases or equivalent to 11.6\%, giving emphasis from the phrase as much as 1 case or equivalent to 3,8\%, indicating an informal relationship or closeness of 4 or 15,4\%, and need lexical 18 cases or equal to 69,2\%.

Keywords: Code switching, Code mixing, Online lectures

\section{PENDAHULUAN}

Perkembangan teknologi dewasa ini telah membawa perubahan baru dalam proses belajar mengajar. Banyak universitas yang kemudian mengembangkan sistem kuliah online yang menggunakan teknologi internet. Unikom juga menjadi salah satu perguruan tinggi yang mengembangkan sistem kuliah online ini. Sistem kuliah online ini memudahkan siswa berkomunikasi dengan dosen meskipun jarak jauh.

Dalam penggunaan kuliah online ini komunikasi antara pengajar dan siswa menjadi hal yang penting untuk bisa menyampaikan pesan secara efektif dan efisien. Pola komunikasi dosen menjadi salah satu faktor penting pesan bisa diterima oleh komunikannya atau tidak. Seorang dosen secara senggaja atau tidak sengaja bisa mengunakan bahasa lain dalam mengkomunikasikan maksudnya. Peralihan bahasa yang digunakan ini disebut dengan alih kode atau campur kode. Secara bidang keilmuan, bahasan mengenai alih kode dan campur kode termasuk dalam kajian sosiolinguistik.

Alih kode bisa terjadi disebabkan oleh berbagai faktor baik hubungan kedekatan komunikator dengan komunikannya, tujuan pembicaraan, variasi bahasa, topik pembahasan, serta waktu dan tempat berbicara. Alih kode dalam pengajaran juga sebagian besar disebabkan oleh ilmu pengetahuan di Indonesia yang masih sangat dipengaruhi oleh perkembangan ilmu pengetahuan Barat sehingga kecenderungan untuk menggunakan istilah-istilah asing masih sangat besar. Selain itu, faktor multilingual --bahasa Indonesia dan bahasa daerah- dari masyarakat Indonesia menyebabkan masyarakat Indonesia terbiasa menggunakan lebih dari satu bahasa. Hal ini memungkinkan terjadinya alih kode dari bahasa Indonesia sebagai bahasa formal yang digunakan ke bahasa daerah atau ke bahasa asing.

Berkaitan dengan uraian diatas, pola komunikasi dosen UNIKOM menggunakan alih kode dan campur kode di kuliah online menjadi hal yang perlu dikaji untuk melihat jenis bentuk dan tujuan dari alih kode atau campur kode tersebut. Kajian ini diharapkan dapat mengobservasi keefektifan komunikasi antara dosen dan mahasiswa.

\section{TINJAUAN PUSTAKA Pengertian Alih Kode dan Campur Kode}

Paul Ohoiwutun di dalam bukunya Sosiolinguistik: Memahami Bahasa dalam Konteks Masyarakat dan Kebudayaan (2007:71) mengungkapkan bahwa alih kode merupakan peralihan pemakaian dari suatu bahasa atau dialek ke bahasa atau dialek lainnya. Adapun penyebab alih bahasa ini terjadi adalah karena adanya perubahan sosiokultural dalam situasi berbahasa. Perubahan tersebut mencakup faktor-faktor seperti hubungan antara pembicara dan pendengar, variasi bahasa, tujuan berbicara, topik yang dibahas, waktu dan tempat berbincang. Lebih lanjut, Chloros (2009:4) mengungkapkan bahwasanya alih kode cenderung terjadi pada individu yang bilingual dan ataupun 
di tengah-tengah masyarakat yang bilingual, yakni masyarakat yang menggunakan bahasa-bahasa yang berlainan (ragam bahasa) yang artinya memakai lebih dari satu bahasa untuk berkomunikasi.

Berkaitan dengan ragam bahasa, Indonesia merupakan salah satu negara yang multilingual. Hal ini disebabkan oleh banyaknya suku di Indonesia; di mana setiap suku tersebut memiliki satu atau lebih bahasa yang digunakan oleh masyarakatnya. Hal ini berdampak terhadap seringnya terjadi pengalihan kode dari bahasa nasional, bahasa Indonesia, ke bahasa daerah maupun sebaliknya. Ditambah lagi, dengan sistem pendidikan di Indonesia, yang memasukkan pelajaran bahasa Indonesia, bahasa daerah, dan bahasa internasional (umumnya bahasa Inggris) sebagai pelajaran yang wajib untuk dipelajari di sekolah. Hal tersebut jelas berdampak terhadap penggunaan bahasa dalam proses komunikasi dan interaksi. Penggunaan ragam bahasa ini ditemukan dalam segala tindak bahasa, baik lisan maupun tulisan, dan penggunaan yang acap terjadi adalah pencampuran atau pengalihan dari bahasa tertentu ke bahasa lainnya, seperti: dari bahasa Indonesia ke bahasa daerah, dari bahasa Indonesia ke bahasa asing, dan dari bahasa daerah ke bahasa asing, maupun sebaliknya.

Berkaitan dengan alih kode, dikenal juga istilah campur kode. Ohoiwutun (2007:69) mengungkapkan bahwa campur kode merupakan gejala di mana fenomena dijumpainya suatu kekacauan atau interferensi bahasa (performance interference) yang berbentuk penggunaan unsur-unsur dari suatu bahasa tertentu dalam satu kalimat atau wacana bahasa lain. Terdapat sedikit perbedaan di antara alih kode dan campur kode. Menurut Ritchie dan Bhatia (2004:337) alih kode berada di tataran intersentential (antar kalimat), sedangkan campur kode ada di tataran intrasentential yakni morfem, kata, frasa, dan klausa yang ada di dalam satu kalimat.

Berkaitan dengan penelitian ini, mengenai perbedaan alih kode dan campur kode penulis mengambil teori dari Poplack (1980), yang dikutip oleh Suzanne Romaine dalam artikelnya LanguageContact Studies (2004:53), diungkapkan bahwa alih kode dibedakan menjadi tiga jenis, yaitu: alih kode tag (tag-switching), alih kode antar kalimat (inter-sentential) dan alih kode intra kalimat (intrasentential). Mengenai alih kode intra kalimat, Romaine menjelaskan bahwa "Intra-sentential switching involves switching within the boundaries of a clause or sentence, as well as within word boundaries" (2004:53). Pengertian tersebut sejalan dengan pengertian campur kode yang diungkapkan oleh Ohoiwutun. Oleh karena itu, penulis berkesimpulan bahwasanya campur kode juga merupakan salah satu jenis alih kode, yakni alih kode intra-sentential.

\section{Jenis Alih Kode dan Campur Kode}

Seperti yang telah dijelaskan di atas, terdapat tiga jenis alih kode; alih kode tag (tag-switching), alih kode antar kalimat (inter-sentential) dan alih kode intra kalimat (intra-sentential) atau yang dikenal juga dengan campur kode. Adapun penjelasan mengenai jenis-jenis tersebut dan berbagai aspek yang berkaitan dengan hal tersebut akan disajikan pada sub bab berikut.

\section{Alih Kode Tag (Tag-Switching)}

Alih kode tag merupakan alih kode yang terjadi pada suatu ujaran dalam bahasa tertentu dengan menyisipkan tag atau yang dikenal dengan istilah 'pengukuh' dari bahasa yang lain. Hal ini seperti terlihat pada kutipan berikut: "Tagswitching involves the insertion of a tag in one language into an utterance which is otherwise entirely in the other language, $e$. g. you know, I mean, etc" (Romaine, 2004:53). Dalam kutipan tersebut, 
Romaine mencontohkan beberapa tag dalam bahasa Inggris, seperti: you know dan I mean.

Untuk lebih memahami penggunaan alih kode tag tersebut, perhatikan contoh berikut: "Saya kurang paham masalahnya, saya harus nanya dulu ke Ani, you know?". Di sini, penutur mengungkapkan ujaran dalam bahasa Indonesia dan menyisipkan tag di akhir ujarannya yakni: 'ýou know?'. Penggunaan tag tersebut walaupun disertai dengan tanda tanya, tapi fungsinya bukan untuk menanyakan kepada mitra tutur, akan tetapi berfungsi sebagai pengukuh ujaran yang disampaikan sebelumnya.

\section{Alih Kode Antar Kalimat(Inter- Sentential Switching)}

Alih kode antar kalimat secara sederhana didefinisikan sebagai alih kode yang terjadi dari satu bahasa ke bahasa lain pada kalimat yang berbeda. Namun, lebih detil, Romaine mengungkapkan sebagai berikut: "Inter-sentential switching involves a switch at a clause or sentence boundary, where each clause or sentence is in one language or another" (Romaine, 2004:53). Kutipan tersebut menjelaskan bahwa alih kode antar kalimat tidak hanya melibatkan antar kalimat, tapi juga bisa melibatkan batas klausa.

Untuk lebih memahami penggunaan alih kode antar kalimat, perhatikan contoh berikut: (a) "I know him well. Dia orang yang baik, kok.", (b) "Seharusnya kalian udah tau bahwa grammar is the most difficult subject!" Dari kedua contoh dapat dilihat, pada contoh (a) terjadi pengalihan kode ke bahasa lain di kalimat yang berbeda, sedangkan contoh (b) terjadi pengalihan kode ke bahasa lain dengan batas antar klausa.

\section{Alih Kode Intra Kalimat(Intra- Sentential Switching) atau Campur Kode (Mixing Code)}

Alih kode intra kalimat secara sederhana didefinisikan sebagai alih kode yang terjadi pada unit-unit bahasa di dalam satu kalimat. Lebih lanjut, Romaine menjelaskan sebagai berikut: "Intrasentential switching involves switching within the boundaries of a clause or sentence, as well as within word boundaries" (Romaine, 2004:53). Kutipan tersebut menjelaskan bahwa alih kode intra kalimat dapat terjadi pada batas klausa, kalimat, dan bahkan kata.

Berkaitan dengan batas klausa dan kalimat tersebut di atas, terdapat dua unit bahasa yang terlibat di dalamnya, yakni: frasa dan kata. Berikut adalah contoh alih kode dari kedua unit bahasa tersebut: (a) "Aku pinjam book kamu ya.." , (b) "Kamu mau pesan orange juice, ga?”. Contoh (a) merupakan alih kode intra kalimat dengan menggunakan unit kata, yakni pada kata 'book', dan (b) merupakan alih kode intra kalimat dengan menggunakan unit frasa, yakni pada frasa 'orange juice'.

Selain unit-unit bahasa yang telah dijelaskan di atas, pada alih kode intra kalimat juga terdapat dua komponen bentukan yang termasuk ke dalam alih kode jenis ini, yaitu: bentuk baster dan pengulangan kata (reduplikasi). Baster adalah hasil perpaduan dua unsur bahasa berbeda yang membentuk satu makna, contohnya: "Aku mau hot kopi aja, deh". Frasa 'hot kopi' disebut baster karena dibentuk dengan memadukan dua unsur bahasa yang berbeda. Sedangkan, pengulangan kata (reduplikasi) adalah penggunaan bentuk kata yang diulang dan disisipkan di dalam klausa ataupun kalimat, contohnya: "Kita walking-walking yuk". Pengulangan kata 'walking-walking' digunakan di dalam kalimat ini sebagai pengganti padanan kata 'jalan-jalan'; hal ini sering digunakan untuk hal yang bersifat jenaka dan dalam situasi yang tidak formal.

Selain unit bahasa dan komponen bentukan yang telah dijelaskan sebelumnya, pada kutipan yang 
diungkapkan Romaine juga mengungkapkan bahwa alih kode intra kalimat dapat juga terjadi pada batasan kata. Hal ini dapat saja terjadi ketika unsur pembentuk kata dari suatu bahasa dicampur kodekan dengan unsur pembentuk kata pada bahasa lainnya. Hal ini biasanya terjadi hanya untuk menimbulkan efek lucu dan kejenakaan; berikut adalah contohnya: "Jantungku hampir copot tadi, si supirman itu bawa angkotnya gila-gilaan". Di sini, kata 'supir' dicampur dengan 'man' yang merupakan salah satu unsur pembentuk kata bahasa Inggris yang menunjukkan jender pelaku kegiatan; biasanya 'man' digunakan di beberapa kata, seperti: policeman dan fireman.

\section{Bentuk Alih Kode dan Campur Kode}

Menurut Hymes (dalam Rahardi, 2001:20) bentuk alih kode dibagi berdasarkan sifatnya menjadi dua yaitu alih kode intern (internal code switching) dan alih kode ekstern (external code switching). Alih kode intern merupakan alih kode yang terjadi antar bahasa daerah dalam suatu bahasa nasional; berkaitan dengan penelitian ini misalnya alih kode yang terjadi dari bahasa Sunda ke bahasa Indonesia. Adapun alih kode ekstern merupakan alih kode yang terjadi antara bahasa nasional dengan bahasa asing; berkaitan dengan penelitian ini misalnya dari bahasa Indonesia beralih ke bahasa Inggris atau bahasa asing lainnya.

Seperti halnya alih kode, campur kode yang juga merupakan bagian dari alih kode juga terbagi dua, yakni: campur kode ke dalam (inner code mixing)dan campur kode ke luar (outer code mixing). Campur kode ke dalam adalah campur kode yang bersumber dari bahasa asli (daerah) dengan segala variasinya; berkaitan dengan penelitian ini misalnya campur kode yang terjadi dari bahasa Sunda ke bahasa Indonesia atau sebaliknya. Campur kode ke luar adalah campur kode yang berasal dari bahasa asing; berkaitan dengan penelitian ini misalnya dari bahasa Indonesia beralih ke bahasa Inggris atau bahasa asing lainnya maupun sebaliknya.

\section{Tujuan Alih Kode dan Campur Kode}

Muriel Saville-Troike di dalam bukunya The Ethnography ofCommunication: An Introduction (2003: 54) mengungkapkan beberapa tujuan penutur melakukan alih kode dan campur kode, yakni sebagai berikut:

a. Memperhalus dan atau menguatkan permintaan ataupun perintah. Hal ini cukup sering dilakukan, misalnya ungkapan permintaan dalam bahasa Indonesia, lalu diakhiri dengan kata 'please?' di akhir ungkapan dengan tujuan untuk menghaluskan permintaan.

b. Mengeliminasi keambiguan. Hal ini terkadang diungkapkan dengan mengulang ungkapan yang sama ke bahasa yang lain untuk menghilangkan keambiguan atau ketidakpahaman dari mitra tutur.

c. Memberikan penekanan pada bagian tertentu dari ungkapan. Hal ini kerap dilakukan sebagai penekanan akan maksud tertentu dan juga dapat sebagai penekanan terhadap emosi penutur.

d. Menunjukkan hubungan yang informal atau kedekatan. Hal ini cukup sering dilakukan penutur, untuk menunjukkan rasa persahabatan dan kedekatan dengan mitra tutur.

e. Menimbulkan efek jenaka atau humor. Hal ini dilakukan untuk menghilangkan kesan serius dan menimbulkan kelucuan dan sebagai satu cara untuk mencairkan suasana.

f. Penggunaan kutipan langsung. Hal ini terjadi bila penutur menyisipkan kutipan, peribahasa, 
dan ataupun perkataan orang terkenal ketika berkomunikasi dengan mitra tutur.

g. Kebutuhan leksikal. Hal ini terjadi apabila penutur tidak dapat menemukan padanan makna suatu kata bahasa asing yang dirasa tepat ke dalam bahasa komunikasi yang digunakannya.

h. Sebagai strategi perbaikan dalam komunikasi. Hal ini diistilahkan oleh Saville-Troike dengan 'repair strategy', dan biasanya dilakukan penutur ketika dia menyadari bahwasanya dia telah menggunakan kode yang tidak sesuai dalm proses komunikasi.

\section{TUJUAN DAN MANFAAT PENELITIAN \\ Tujuan Penelitian}

Adapun tujuan penelitian ini adalah sebagai berikut:

1. Untuk menganalisis jenis alih kode dan campur kode yang ditemukan pada pola komunikasi dosen UNIKOM di aplikasi Kuliah Online UNIKOM.

2. Untuk menganalisis bentuk alih kode dan campur kode yang ditemukan pada pola komunikasi dosen UNIKOM di aplikasi Kuliah Online UNIKOM.

3. Untuk menjelaskan tujuan dari penggunaan alih kode dan campur kode tersebut.

\section{Manfaat Penelitian}

Penelitian ini diharapkan dapat memberi manfaat, baik secara teoritis maupunpraktis.Secara teoritis, penelitian ini diharapkan dapat memberikan manfaat untuk pengembangan keilmuan dan pengetahuan di bidang linguistik, terutama sosiolinguitik. Adapun secara praktis, penelitian ini diharapkan dapat memberikan manfaat untuk mengembangkan kemampuan komunikasi yang efektif dalam menjalin silaturrahmi dan bersosialisasi di tengah masyarakat.

\section{METODE PENELITIAN Metode dan Teknik Metode}

Penelitian ini merupakan penelitian deskriptif kualitatif yang mengkaji fenomena kebahasaan dengan pendekatan sosiolinguistik. Analisis data penelitian ini menggunakan metode analisis deskriptif, yang mengacu pada fakta dan fenomena yang hidup secara empiris.

Secara umum, metode yang digunakan dalam penelitian ini adalah metode kualitatif. Bogdan dan Biklin (1992:29) mengungkapkan bahwa:

a. Penelitian kualitatif bersifat deskriptif.

b. Data yang dikumpulkan umumnya berbentuk kata-kata.

c. Penelitian kualitatif lebih mementingkan proses dibanding produk jadi.

d. Penelitian kualitatif menganalisis data secara logis.

e. Makna merupakan fokus yang esensial pada penelitian kualitatif.

\section{Teknik Pengumpulan Data}

Pengumpulan data adalah salah satu hal pokok yang harus dilakukan sebagai sebuah langkah awal dalam melakukan penelitian. Adapun tujuan utama dari pengumpulan data adalah untuk mendapatkan data yang valid dan akurat. Berkenaan dengan penelitian ini, teknik pengumpulan data yang digunakan adalah purposive sampling; hal ini dilakukan karena penelitian ini bertujuan untuk mengetahui karakteristik jenis, bentuk, dan tujuan pemakaian alih kode dan campur kode. Adapun sampel yang diambil dalam penelitian ini adalah status atau informasi yang diungkapkan oleh dosen-dosen 
UNIKOM di dalam aplikasi Kuliah Online UNIKOM yang dapat diakses di http://kuliahonline.unikom.ac.id.

Untuk menyokong analisis, umumnya ada beberapa metode yang aplikabel dan acap digunakan, seperti: metode penelitian kepustakaan (library research), metode penelitian lapangan (field research), dan metode penelitian laboratorium (laboratory research). Namun, untuk penelitian ini, hanya metode penelitian kepustakaan (library research) yang digunakan. Metode ini dianggap paling sesuai dalam melakukan penelitian seperti ini.

Dalam pengumpulan data, ada beberapa prosedur yang dilakukan, yakni sebagai berikut:

1. Memilih sumber data Dalam melakukan penelitian ini, sumber data yang dibutuhkan haruslah valid dan akurat, serta tepat sasaran sesuai dengan topik penelitian yang diangkat. Adapun sumber data dalam penelitian ini adalah status atau informasi yang diungkapkan oleh dosen-dosen UNIKOM di dalam aplikasi Kuliah Online UNIKOM yang dapat diakses di http://kuliahonline.unikom.ac.id.

2. Membaca keseluruhan status atau informasi tersebut secara komprehensif dan menyeluruh.

3. Memilih data Pada proses ini, data yang dipilih berupa kata, frasa, klausa dan kalimat yang berhubungan dengan alih kode dan campur kode.

4. Menganalisis data

Setelah proses pemilihan data, data terpilih, lalu dianalisis dengan melihat jenis, bentuk, dan tujuan alih kode dan campur kode yang terlibat di dalamnya.

\section{HASIL PENELITIAN DAN PEMBAHASAN \\ Jenis Alih Kode dan Campur Kode}

\section{pada pola komunikasi dosen UNIKOM di aplikasi Kuliah Online}

Seperti yang telah dijelaskan di bagian sebelumnya, terdapat tiga jenis alih kode; alih kode tag (tag-switching), alih kode antar kalimat (inter-sentential) dan alih kode intra kalimat (intra-sentential) atau yang dikenal juga dengan campur kode. Adapun hasil penelitian menunjukkan terdapat 44 kasusterjadinya alih kode dan campur kode pada pola komunikasi dosen UNIKOM di aplikasi Kuliah Online. Dari total kasus tersebut, jenis alih kode yang paling banyak terjadi adalah alih kode intra kalimat atau yang dikenal juga dengan campur kode; persentase penggunaan jenis ini mencapai $86,3 \%$ atau setara dengan 38 kasus. Sebaliknya, jenis alih kode yang paling sedikit terjadi adalah alih kode tag; persentase penggunaannya hanya 2,3\% atau setara dengan 1 kasus. Sedangkan, jenis alih kode antar kalimat/klausa mencapai persentase $11,4 \%$ atau setara dengan 5 kasus. Pemaparan lebih detil mengenai setiap jenis alih kode tersebut akan dibahas pada sub bab berikut.

\section{Alih Kode intra kalimat (Campur Kode)}

Seperti yang telah dijelaskan di bab sebelumnya, alih kode intra kalimat merupakan alih kode yang terjadi di dalam satu kalimat yang sama. Oleh karena itulah, jenis alih kode ini juga disebut dengan campur kode. Pada penggunaannya, jenis alih kode ini dapat muncul dari beberapa tataran unit bahasa, yakni: kata, frasa, dan baster (frasa yang dibentuk dari dua atau lebih unit kata dari bahasa yang berbeda). Berikut adalah pemaparan hasil dan pembahasan mengenai alih kode jenis ini.

Data 1.

Latihan: Untuk yg ngambil mata kuliah PHP MYSQL "Buat aplikasi seperti Fesbuk" minimal bisa registrasi, update status, reply dan melihat relationship 
antar member" cukup 2 malem aja, senen yg udah boleh demo...

Di data tersebut, terdapat beberapa alih kode intra kalimat yang muncul. Adapun pada data terdapat dua kasus alih kode yang muncul dalam unit frasa, yakni: update status (frasa verba), cukup 2 malem aja (frasa nomina); sedangkan, yang muncul dalam unit kata terdapat dua kasus, yakni: reply (kata kerja), Senen(kata benda); yang muncul dalam unit baster terdapat tiga kasus, yakni: melihat relationship (baster yang dibentuk dalam frasa verba), antar member (baster yang dibentuk dalam frasa preposisi), dan boleh demo (baster yang dibentuk dalam frasa verba).

\section{Data 2}

Untuk seluruh mahasiswa yang ngambil matakuliah E-Commerce, UAS akan dilaksanakan pada minggu kedua, tanggal 18-23 Januari 2010.. sok atuh belajar yahhh, pelajari modul input dan tampil data...

Pada data di atas terdapat dua kasus alih kode intra kalimat yang muncul dalam unit baster, yakni: matakuliah $E$ Commerce (baster yang dibentuk dalam frasa nomina) dan modul input dan tampil data (baster yang dibentuk dalam frasa nomina).

\section{Data 3}

Untuk Mahasiswa Jurusan akuntansi Kelas $A K-1, A K-5$ dan $A K-B U$, yang mengambil matakuliah IT-1, meteri kuliah mengenai java script silahkan download disini atau di kuliah online.

Di data tersebut, terdapat beberapa alih kode intra kalimat yang muncul. Terdapat dua kasus alih kode intra kalimat yang muncul dalam unit baster, yakni: silahkan download (baster yang dibentuk dalam frasa verba) dan kuliah online(baster yang dibentuk dalam frasa nomina). Selain itu, terdapat juga satu kasus alih kode intra kalimat yang muncul dalam unit frasa, yakni: java script.

\section{Data 4}

For all my student, SEGERA masuk ke kelas dalam Media Kuliah On-Line yaa ... SEMANGAT !!

Pada data di atas terdapat dua kasus alih kode intra kalimat. Kasus yang pertama muncul dalam unit frasa, yakni: for all my student (frasa preposisi), dan kasus kedua muncul dalam unit baster, yakni: media kuliah on-line (baster yang dibentuk dalam frasa nomina).

\section{Data 5}

UTS AI bersifat Open Book, yg oleh dilihat hanya buku dan catatan msg2. ebook dan internet tidak diijinkan. tidak ada saling pinjam catatan. selamat belajar

Pada data di atas terdapat dua kasus alih kode intra kalimat. Kasus yang pertama muncul dalam unit frasa, yakni: open book (frasa nomina), dan kasus kedua muncul dalam unit kata, yakni: ebook (kata benda).

\section{Data 6}

Kepada mahasiswa HI, semua bahan untuk referensi UTS sudah diupload. silakan didownload. selamat belajar.

Pada data di atas terdapat dua kasus alih kode intra kalimat yang muncul dalam unit kata, yakni: diupload (kata kerja) dan didownload (kata kerja). Pada dasarnya, kedua kasus tersebut merupakan temuan yang menarik karena terdapat pembentukan kata yang memadukan dua unsur bahasa yang berbeda. Kata kerja yang digunakan dalam data tersebut merupakan bentukan pasif, namun dibentuk oleh imbuhan ' $d i$-' dalam bahasa Indonesia, dan 'upload' dan 'download' dalam bahasa Inggris. Kasus ini tidak bisa dikategorikan baster karena muncul pada satu kata yang sama; penggunaan kata yang seharusnya tepat untuk digunakan adalah 'diunggah' dan 'diunduh'.

\section{Data 7}

Template tugas besar sudah dapat diunduh 
di kelas Materi AI 14-15. Thx

Pada data di atas terdapat satu kasus alih kode intra kalimat yang muncul dalam unit baster, yakni: template tugas besar (baster yang dibentuk dalam frasa nomina).

\section{Data 8}

Untuk yg mengambil metli, silahkan sesuaikan susunan UP Anda dengan contoh UP yg telah saya upload di kelas MATERI. Lalu Perhatikan Instruksinya.

Pada data di atas terdapat satu kasus alih kode intra kalimat yang muncul dalam unit kata, yakni: upload (kata kerja).

\section{Data 9}

Kelas AI-1 dan AI-8 disk tugas besar silakan simpan di meja saya. Quiz dilaksanakan minggu depan. Thx

Pada data di atas terdapat dua kasus alih kode intra kalimat. Kasus yang pertama muncul dalam unit baster, yakni: disk tugas besar (baster yang dibentuk dalam frasa nomina), dan kasus kedua muncul dalam unit kata, yakni: quiz (kata benda).

\section{Data 10}

Utk kelas Humas, praktek public speaking $r$ 4413, dapat dilihat nama2 yg boleh susulan di materi online, makasih

Pada data di atas terdapat dua kasus alih kode intra kalimat yang muncul dalam unit baster, yakni: praktek public speaking (baster yang dibentuk dalam frasa nomina) dan materi online(baster yang dibentuk dalam frasa nomina).

\section{Data 11}

Kelas Alien 4 hari ini, 9 desember 2014 tidak ada perkuliahan, tetapi ada tugas yang wajib dikumpulkan minggu depan. Terimakasih

Pada data di atas terdapat satu kasus alih kode intra kalimat yang muncul dalam unit baster, yakni: kelas Alien 4 (baster yang dibentuk dalam frasa nomina).

\section{Data 12}

Assalamu'alaikum Wr. Wb.Kepada Seluruh Mahasiswa SI-3 dan SI-4 yang mengambil matakuliah KWN, pelajari materi DEBAT di list Pengumuman kuliah Online. Trims.

Pada data di atas terdapat satu kasus alih kode intra kalimat yang muncul dalam unit baster, yakni: list pengumuman kuliah online (baster yang dibentuk dalam frasa nomina).

\section{Data 13}

Materi knowledge representation $d p t$ diunduh di kelas kecerdasan buatan. terima kasih

Pada data di atas terdapat satu kasus alih kode intra kalimat yang muncul dalam unit baster, yakni: materi knowledge representation(baster yang dibentuk dalam frasa nomina).

\section{Data 14}

Salam Hangat, Untuk KSIIO - Silahkan Download Ulang Kompilasi Tugas II karena ada perubahan. Terima kasih

Pada data di atas terdapat satu kasus alih kode intra kalimat yang muncul dalam unit baster, yakni: download ulang(baster yang dibentuk dalam frasa verba).

\section{Data 15}

Salam Hangat, Khusus untuk KSI8 Mohon mendownload File Kompilasi Tugas II Terbaru. Terima kasih

Pada data di atas terdapat dua kasus alih kode intra kalimat. Kasus yang pertama muncul dalam unit kata, yakni: mendownload (kata kerja), dan kasus kedua muncul dalam unit baster, yakni: file Kompilasi Tugas II (baster yang dibentuk dalam frasa nomina). Seperti halnya di data 6 , pada data ini juga terdapat temuan yang menarik, yakni pembentukan kata 'mendownload'. Kata kerja yang digunakan dalam data tersebut merupakan bentukan aktif, namun dibentuk oleh 
imbuhan 'men-' dalam bahasa Indonesia, dan 'download' dalam bahasa Indonesia. Kasus ini tidak bisa dikategorikan baster karena muncul pada satu kata yang sama.

\section{Data 16}

Buat Mahasiswa IP Mk Prolegm quiz online silahkan dikerjakan. informasi lebih lanjut, silahkan lihat pengumuman di kelas online.

Pada data di atas terdapat dua kasus alih kode intra kalimat yang muncul dalam unit baster, yakni: quiz online (baster yang dibentuk dalam frasa nomina) dan kelas online(baster yang dibentuk dalam frasa nomina). Pada data ini juga terdapat temuan yang menarik, frasa 'quiz online' pada prinsipnya dibentuk oleh dua kata bahasa Inggris: 'quiz' dan 'online'; akan tetapi pembentukan frasanya tidak sesuai dengan kaidah bahasa Inggris (MD= Menerangkan-Diterangkan) yang seharusnya frasanya menjadi 'online quiz', melainkan masih menggunakan kaidah bahasa Indonesia (DM= DiterangkanMenerangkan). Jadi, ini merupakan kasus baru terhadap pembentukan baster, yakni dibentuk oleh dua kata dalam bahasa yang sama namun masih mengikuti kaidah pembentukan bahasa sumber.

\section{Data 17}

untuk kelas Matdisk-4 dan matdisk-5 silakan lihat kelas materi Matdisk 14-15 untukmendapat hasil review makalah tugas besar.terima kasih

Pada data di atas terdapat satu kasus alih kode intra kalimat yang muncul dalam unit baster, yakni: hasil review(baster yang dibentuk dalam frasa nomina).

\section{Data 18}

Clue Capture The Flag dapat dilihat di http://kuliahonline.unikom.ac.id/?kelas/\&S endPengumuman $=N D M 2 N w \% 3 D \% D$

Pada data di atas terdapat satu kasus alih kode intra kalimat yang muncul dalam unit frasa, yakni: Clue Capture The Flag (frasa nomina).

\section{Data 19}

Server CTF akan ditutup pada tanggal 25 Mei. Ayoo segera dapatkan flagnya!

Pada data di atas terdapat dua kasus alih kode intra kalimat yang muncul dalam unit kata, yakni: server(kata benda) dan flag (kata benda).

\section{Data 20}

CTF Online untuk kelas Information Security telah ditutup. Terimakasih telah bermain (:

Pada data di atas terdapat dua kasus alih kode intra kalimat yang muncul dalam unit baster, yakni: CTF Online (baster yang dibentuk dalam frasa nomina) dan kelas Information Security(baster yang dibentuk dalam frasa nomina).

\section{Alih Kode Tag}

Alih kode tag merupakan alih kode yang terjadi pada suatu ujaran dalam bahasa tertentu dengan menyisipkan tag atau yang dikenal dengan istilah 'pengukuh' dari bahasa yang lain. Berkaitan dengan penelitian yang dilakukan, hanya terdapat satu kasus penggunaan alih kode tag, yakni yang terdapat pada data berikut:

\section{Data 21}

Minggu depan asistensi visual, nya? jangan lupa alternatif2 ide...

Pada data di atas terdapat kasus alih kode tag, yakni dengan menyisipkan pengukuh 'nya?'. Pada kasus ini, pernyataan yang muncul dalam bahasa Indonesia, diberi pengukuh di bagian akhir dalam bahasa Sunda.

\section{Alih Kode Antar Kalimat}


Alih kode antar kalimat merupakan alih kode yang terjadi dari satu bahasa ke bahasa lain pada kalimat atau klausa yang berbeda. Berkaitan dengan penelitian ini, terdapat tiga kasus penggunaan alih kode antar kalimat, yakni yang terdapat pada data-data berikut:

\section{Data 22}

For all my students do not too lazy. Persiapan buat quiznya...

Pada data di atas terdapat kasus alih kode antar kalimat. Pernyataan dalam bahasa Inggris 'For all my students do not too lazy' dialihkodekan dengan pernyataan lain dalam bahasa Indonesia pada kalimat yang berbeda 'Persiapan buat quiznya'.

\section{Data 23}

Untuk seluruh mahasiswa yang ngambil matakuliah E-Commerce, UAS akan dilaksanakan pada minggu kedua, tanggal 18-23 Januari 2010.. sok atuh belajar yahhh, pelajari modul input dan tampil data...

Pada data di atas terdapat kasus alih kode antar kalimat. Bila ditilik dari klausa-klausa yang terlibat dalam kalimat ini, terdapat tiga klausa yang digunakan, yakni: klausa 1 'Untuk seluruh mahasiswa yang ngambil matakuliah E-Commerce, UAS akan dilaksanakan pada minggu kedua, tanggal 18-23 Januari 2010', klausa 2 'sok atuh belajar yahhh', dan klausa 3 'pelajari modul input dan tampil data'. Dari data dapat disimpulkan secara umum bahasa utama yang digunakan adalah bahasa Indonesia; hal ini terlihat dari klausa pertama dan ketiga yang digunakan penutur. Alih kode terjadi pada klausa kedua; penutur mengalihkodekan bahasa yang digunakannya ke pernyataan dalam bahasa Sunda.

\section{Data 24}

Kuliah pengganti untuk kelas MI 7,8,9 yang mengambil matakuliah php. Pengganti tanggal merah selama 4 kali pertemuan diganti hari ini senin-kamis 4-7
Januari 2010, waktu dan tempat sama seperti kuliah biasa... Nuhun.

Pada data di atas hanya terdapat satu kasus alih kode antar kalimat. Kata nuhunpada data di atas sejatinya adalah sebuah kalimat yang dielipsiskan; adapun kalimat yang dimaksud adalah: "Abdi ngahaturkeun nuhun”. Di sini, terjadi elipsis fungsi subjek "abdi" dan predikat "ngahaturkeun", dan hanya menyisakan objek "nuhun".

\section{Data 25}

Template tugas besar sudah dapat diunduh di kelas Materi AI 14-15. Thx

Pada data di atas terdapat satu kasus alih kode antar kalimat. Kata "thx" diasumsikan sebagai singkatan dari kata "thanks" Secara struktur bahasa, kata tersebut sejatinya adalah sebuah kalimat yang dielipsiskan; adapun kalimat yang dimaksud adalah: "I say thanks to your attention". Di sini, terjadi elipsis fungsi subjek " $I$ ", predikat atau verba "say", objek setelah preposisi "to your attention", dan hanya menyisakan objek "thanks".

\section{Data 26}

Assalamu'alaikum Wr. Wb.Kepada Seluruh Mahasiswa SI-3 dan SI-4 yang mengambil matakuliah KWN, pelajari materi DEBAT di list Pengumuman kuliah Online. Trims.

Pada data di atas terdapat satu kasus alih kode antar kalimat, yakni penggunaan kalimat "Assalamu'alaikum Wr (Warahmatullahi). Wb (Wabarakatuh)". Kalimat tersebut berasal dari bahasa Arab yang memiliki arti "semoga diberikan keselamatan atasmu, dan rahmat Allah serta berkah-Nya juga kepadamu."

\section{Bentuk Alih Kode dan Campur Kode pada pola komunikasi dosen UNIKOM diaplikasi Kuliah Online}

Bentuk alih dan campur kode terbagi menjadi dua, yakni: alih dan campur kode 
intern dan ekstern. Alih dan campur kode intern merupakan alih/campur kode yang terjadi antar bahasa daerah dalam suatu bahasa nasional; sedangkan, alih dan campur kode ekstern merupakan alih/campur kode yang terjadi antara bahasa nasional dengan bahasa asing. Berkaitan dengan penelitian ini, yang dikategorikan sebagai bahasa nasional adalah bahasa Indonesia karena bahasa inilah yang digunakan secara formal di aplikasi kuliah online tersebut, dan yang dikategorikan sebagai bahasa asing adalah bahasa Inggris atau bahasa asing lainnya yang familiar atau cukup dipahami oleh penutur dan mitra tutur di aplikasi tersebut. Adapun hasil penelitian menunjukkan dari 44 kasus alih dan campur kode yang terjadi, terdapat $11,4 \%$ penggunaan bentuk alih dan campur kode intern atau setara dengan 5 kasus; sedangkan, bentuk ekstern mencapai $88,6 \%$ atau setara dengan 39 kasus. Pemaparan detil mengenai hasil dan pembahasan mengenai bentuk alih dan campur kode yang ditemukan pada penelitian akan dibahas di sub bab berikut ini.

\section{Alih Kode dan Campur Kode Intern}

Pemaparan pada sub bab mengenai bentuk alih kode dan campur kode ini mengacu pada data yang sama dengan pembahasan mengenai jenis alih kode dan campur kode pada sub-sub bab sebelumnya. Berikut adalah pembahasan mengenai bentuk alih dan campur kode dimaksud.

Pada data 1 terdapat alih dan campur kode intern dari bahasa Indonesia ke bahasa daerah. Penutur menggunakan frasa '2 malem'dan kata 'Senen' yang bersumber dari bahasa Betawi di dalam kalimat yang dituturkannya.

Pada data 24terdapat alih dan campur kode intern dari bahasa Indonesia ke bahasa Sunda. Penutur menggunakan kata 'nuhun' yang merupakan bentuk kalimat yang telah mengalami proses elipsis. Adapun kata atau bentukan elipsis kalimat tersebut bersumber dari bahasa Sunda.

Pada data 21 terdapat alih kode intern dari bahasa Indonesia ke bahasa Sunda. Penutur menggunakan pengukuh 'nya?' yang bersumber dari bahasa Sunda di dalam kalimat yang dituturkannya.

Pada data 23 terdapat alih kode intern dari bahasa Indonesia ke bahasa Sunda. Penutur menggunakan klausa 'sok atuh belajar yahh' yang bersumber dari bahasa Sunda di dalam kalimat yang dituturkannya.

\section{Alih Kode dan Campur Kode Ekstern}

Pada data 1 terdapat alih dan campur kode ekstern dari bahasa Indonesia ke bahasa Inggris. Penutur menggunakan frasa 'update status', dan kata reply, serta baster 'melihat relationship', 'boleh demo', dan 'antar member' di dalam kalimat yang dituturkannya.

Pada data 2 terdapat alih dan campur kode ekstern dari bahasa Indonesia ke bahasa Inggris. Penutur menggunakan baster 'matakuliah E-Commerce'dan 'modul input dan tampil data'di dalam kalimat yang dituturkannya.

Pada data 3 terdapat alih dan campur kode ekstern dari bahasa Indonesia ke bahasa Inggris. Penutur menggunakan baster 'silahkan download', 'kuliah online', dan frasa 'java script' di dalam kalimat yang dituturkannya.

Pada data 4 terdapat alih dan campur kode ekstern dari bahasa Indonesia ke bahasa Inggris. Penutur menggunakan frasa 'for all my student' dan baster 'media kuliah on-line' di dalam kalimat yang dituturkannya.

Pada data 5 terdapat alih dan campur kode ekstern dari bahasa Indonesia ke bahasa Inggris. Penutur menggunakan frasa 'open book' dan kata 'ebook' di dalam kalimat yang dituturkannya.

Pada data 6 terdapat alih dan campur kode ekstern dari bahasa Indonesia 
ke bahasa Inggris. Penutur menggunakan kata 'diupload' dan 'didownload' di dalam kalimat yang dituturkannya.

Pada data 7 terdapat alih dan campur kode ekstern dari bahasa Indonesia ke bahasa Inggris. Penutur menggunakan baster 'template tugas besar' di dalam kalimat yang dituturkannya.

Pada data 8 terdapat alih dan campur kode ekstern dari bahasa Indonesia ke bahasa Inggris. Penutur menggunakan kata 'upload' di dalam kalimat yang dituturkannya.

Pada data 9 terdapat alih dan campur kode ekstern dari bahasa Indonesia ke bahasa Inggris. Penutur menggunakan baster 'disk tugas besar' dan kata 'quiz' di dalam kalimat yang dituturkannya.

Pada data 10 terdapat alih dan campur kode ekstern dari bahasa Indonesia ke bahasa Inggris. Penutur menggunakan baster 'praktek public speaking' dan 'materi online' di dalam kalimat yang dituturkannya.

Pada data 11 terdapat alih dan campur kode ekstern dari bahasa Indonesia ke bahasa Inggris. Penutur menggunakan baster 'kelas Alien 4' di dalam kalimat yang dituturkannya.

Pada data 12 terdapat alih dan campur kode ekstern dari bahasa Indonesia ke bahasa Inggris. Penutur menggunakan baster 'list pengumuman kuliah online' di dalam kalimat yang dituturkannya.

Pada data 13 terdapat alih dan campur kode ekstern dari bahasa Indonesia ke bahasa Inggris. Penutur menggunakan baster 'materi knowledge representation' di dalam kalimat yang dituturkannya.

Pada data 14 terdapat alih dan campur kode ekstern dari bahasa Indonesia ke bahasa Inggris. Penutur menggunakan baster 'download ulang' di dalam kalimat yang dituturkannya.

Pada data 15 terdapat alih dan campur kode ekstern dari bahasa Indonesia ke bahasa Inggris. Penutur menggunakan kata 'mendownload' dan baster 'file Kompilasi Tugas II' di dalam kalimat yang dituturkannya.

Pada data 16 terdapat alih dan campur kode kode ekstern dari bahasa Indonesia ke bahasa Inggris. Penutur menggunakan baster 'quiz online'dan 'kelas online' di dalam kalimat yang dituturkannya.

Pada data 17 terdapat alih kode ekstern dari bahasa Indonesia ke bahasa Inggris. Penutur menggunakan baster "hasil review"'di dalam kalimat yang dituturkannya.

Pada data 18 terdapat alih kode ekstern dari bahasa Indonesia ke bahasa Inggris. Penutur menggunakan frasa "Clue capture the flag"'di dalam kalimat yang dituturkannya.

Pada data 19 terdapat alih dan campur kode kode ekstern dari bahasa Indonesia ke bahasa Inggris. Penutur menggunakan kata 'server'dan 'flag' di dalam kalimat yang dituturkannya.

Pada data 20 terdapat alih dan campur kode kode ekstern dari bahasa Indonesia ke bahasa Inggris. Penutur menggunakan baster 'CTF online'dan 'kelasInformation Security' di dalam kalimat yang dituturkannya.

Pada data 22 terdapat alih kode ekstern dari bahasa Indonesia ke bahasa Inggris. Penutur menggunakan kalimat 'For all my students do not too lazy'di dalam ujaran yang dituturkannya.

Pada data 25 terdapat alih kode ekstern dari bahasa Indonesia ke bahasa Inggris. Penutur menggunakan kata 'Thx (thanks)' yang merupakan bentukan elipsis dari kalimat,di dalam ujaran yang dituturkannya.

Pada data 26 terdapat alih kode ekstern dari bahasa Indonesia ke bahasa Arab. Penutur menggunakan kalimat “Assalamu'alaikum Wr. Wb.'di dalam ujaran yang dituturkannya.

Tujuan Penggunaan Alih Kode dan Campur Kode pada pola komunikasi dosen UNIKOM di aplikasi Kuliah Online 
Seperti yang telah dijelaskan di bagian sebelumnya, secara umum terdapat delapan tujuan penggunaan alih kode dan campur kode, yakni untuk: (a) memperhalus dan atau menguatkan permintaan ataupun perintah,(b) mengeliminasi keambiguan, (c) memberikan penekanan pada bagian tertentu dari ungkapan, (d) menunjukkan hubungan yang informal atau kedekatan, (e)menimbulkan efek jenaka atau humor, (f)penggunaan kutipan langsung, (g)kebutuhan leksikal, dan (h)sebagai strategi perbaikan dalam komunikasi.

Berkaitan dengan penelitian ini, dari total 26 data terjadinya alih dan campur kode, hanya empat tujuan alih dan campur kode yang ditemukan, yakni: memperhalus permintaan sebanyak 3 kasus atau setara $11,6 \%$, memberikan penekanan dari ungkapan sebanyak 1 kasus atau setara 3,8\%, menunjukkan hubungan yang informal/kedekatan sebanyak 4 kasus atau setara 15,4\%, dan kebutuhan leksikal sebanyak 18 kasus atau setara 69,2\%. Adapun penjelasan detil mengenai hal tersebut dapat dilihat di paragraf-paragraf berikut ini.

Pada data 1 tujuan penutur mengalih dan mencampur kodekan pernyataannya adalah untuk menunjukkan hubungan yang informal atau kedekatan. Hal ini bisa dilihat dari penggunaan beberapa kata dan frasa yang bersifat informal, seperti: 'update status', '2 malem aja', 'senen' dan beberapa kata lainnya. Terlihat sekali penutur berusaha mendapatkan perhatian mitra tuturnya dengan memperlihatkan kedekatan hubungan dengan mitra tuturnya.

Pada data 2 dan data 23 tujuan penutur mengalih dan mencampur kodekan pernyataannya adalah untuk menunjukkan hubungan yang informal atau kedekatan. Hal ini bisa dilihat dari penggunaan beberapa kata dan klausa yang bersifat informal, seperti: 'ngambil', dan 'sok atuh belajar yahh'. Terlihat sekali penutur berusaha mendapatkan perhatian mitra tuturnya dengan memperlihatkan kedekatan hubungan dengan mitra tuturnya. Di sisi lain, tujuan penutur mengalih dan mencampur kodekan pernyataannya adalah sebagai kebutuhan leksikal, penutur mengalih dan mencampur kodekan pernyataannya dengan istilah yang umum digunakan dan familiar bagi mitra tutur, seperti: 'matakuliah $E$ Commerce'.

Pada data 3 tujuan penutur mengalih dan mencampur kodekan pernyataannya adalah sebagai kebutuhan leksikal. Pada pernyataannya, penutur menggunakan bahasa formal yang berisikan permintaan. Karena bertemakan komputer, penutur mengalih dan mencampur kodekan pernyataannya dengan istilah yang umum digunakan dan familiar bagi mitra tutur, seperti: 'java script' dan 'kuliah online'.

Pada data 4 tujuan penutur mengalih dan mencampur kodekan pernyataannya adalah untuk menunjukkan hubungan yang informal atau kedekatan. Hal ini bisa dilihat dari penggunaan alih dan campur kode tersebut, serta bentuk penulisan yang mencampur dengan huruf kapital dan tanda baca yang informal. Terlihat sekali penutur berusaha mendapatkan perhatian mitra tuturnya dengan memperlihatkan kedekatan hubungan dengan mitra tuturnya.

Pada data 5 tujuan penutur mengalih dan mencampur kodekan pernyataannya adalah sebagai kebutuhan leksikal. Pada pernyataannya, penutur menggunakan bahasa formal yang berisikan permintaan. Penutur mengalih dan mencampur kodekan pernyataannya dengan istilah yang umum digunakan dan familiar bagi mitra tutur, seperti: 'open book' dan 'ebook'.

Pada data 6 tujuan penutur mengalih dan mencampur kodekan pernyataannya adalah sebagai kebutuhan leksikal. Pada pernyataannya, penutur menggunakan bahasa formal yang 
berisikan permintaan. Penutur mengalih dan mencampur kodekan pernyataannya dengan istilah yang umum digunakan dan familiar bagi mitra tutur, seperti: 'didownload' dan 'diupload'.

Pada data 7 dan 25 tujuan penutur mengalih dan mencampur kodekan pernyataannya adalah sebagai kebutuhan leksikal. Penutur mengalih dan mencampur kodekan pernyataannya dengan istilah yang umum digunakan dan familiar bagi mitra tutur, yakni: 'template tugas besar'. Di sisi lain, penutur juga bertujuan untuk memperhalus pernyataannya dengan mengakhiri pernyataannya dengan 'thx (=thanks)' yang menyiratkan ungkapan terima kasih.

Pada data 8 tujuan penutur mengalih dan mencampur kodekan pernyataannya adalah sebagai kebutuhan leksikal. Pada pernyataannya, penutur menggunakan bahasa formal yang berisikan permintaan. Penutur mengalih dan mencampur kodekan pernyataannya dengan istilah yang umum digunakan dan familiar bagi mitra tutur.

Pada data 9 tujuan penutur mengalih dan mencampur kodekan pernyataannya adalah sebagai kebutuhan leksikal. Penutur mengalih dan mencampur kodekan pernyataannya dengan istilah yang umum digunakan dan familiar bagi mitra tutur, seperti: 'disk tugas besar' dan 'quiz'. Di sisi lain, penutur juga bertujuan untuk memperhalus pernyataannya dengan mengakhiri pernyataannya dengan 'thx (=thanks)' yang menyiratkan ungkapan terima kasih.

Pada data 10 tujuan penutur mengalih dan mencampur kodekan pernyataannya adalah sebagai kebutuhan leksikal. Pada pernyataannya, penutur menggunakan bahasa formal yang berisikan permintaan. Penutur mengalih dan mencampur kodekan pernyataannya dengan istilah yang umum digunakan dan familiar bagi mitra tutur, seperti: 'praktek public speaking' dan 'materi online'.
Pada data 11 tujuan penutur mengalih dan mencampur kodekan pernyataannya adalah sebagai kebutuhan leksikal. Pada pernyataannya, penutur menggunakan bahasa formal yang berisikan permintaan. Penutur mengalih dan mencampur kodekan pernyataannya dengan istilah yang umum digunakan dan familiar bagi mitra tutur, seperti: "kelas Alien 4'.

Pada data 12 dan 26 tujuan penutur mengalih dan mencampur kodekan pernyataannya adalah sebagai kebutuhan leksikal. Penutur mengalih dan mencampur kodekan pernyataannya dengan istilah yang umum digunakan dan familiar bagi mitra tutur, seperti: 'list pengumuman kuliah online'. Di sisi lain, penutur juga bertujuan untuk memperhalus pernyataannya dengan mengawali pernyataannya dengan salam 'Assalamualaikum Wr. Wb.'

Pada data 13 tujuan penutur mengalih dan mencampur kodekan pernyataannya adalah sebagai kebutuhan leksikal. Penutur mengalih dan mencampur kodekan pernyataannya dengan istilah yang umum digunakan dan familiar bagi mitra tutur, seperti: 'materi knowledge representation'.

Pada data 14 dan 15 tujuan penutur mengalih dan mencampur kodekan pernyataannya adalah sebagai kebutuhan leksikal. Pada pernyataannya, penutur menggunakan bahasa formal yang berisikan permintaan. Penutur mengalih dan mencampur kodekan pernyataannya dengan istilah yang umum digunakan dan familiar bagi mitra tutur.

Pada data 16 tujuan penutur mengalih dan mencampur kodekan pernyataannya adalah sebagai kebutuhan leksikal. Pada pernyataannya, penutur menggunakan bahasa formal yang berisikan permintaan. Penutur mengalih dan mencampur kodekan pernyataannya dengan istilah yang umum digunakan dan familiar bagi mitra tutur, seperti: 'quiz online'. 
Pada data 17 tujuan penutur mengalih dan mencampur kodekan pernyataannya adalah sebagai kebutuhan leksikal. Penutur mengalih dan mencampur kodekan pernyataannya dengan istilah yang umum digunakan dan familiar bagi mitra tutur, seperti: 'hasil review makalah tugas besar'.

Pada data 18 tujuan penutur mengalih dan mencampur kodekan pernyataannya adalah sebagai kebutuhan leksikal. Penutur mengalih dan mencampur kodekan pernyataannya dengan istilah yang umum digunakan dan familiar bagi mitra tutur, seperti: 'Clue capture The flag'.

Pada data 19 tujuan penutur mengalih dan mencampur kodekan pernyataannya adalah sebagai kebutuhan leksikal. Penutur mengalih dan mencampur kodekan pernyataannya dengan istilah yang umum digunakan dan familiar bagi mitra tutur, seperti: 'Server CTF' dan 'flag'.

Pada data 20 tujuan penutur mengalih dan mencampur kodekan pernyataannya adalah sebagai kebutuhan leksikal. Penutur mengalih dan mencampur kodekan pernyataannya dengan istilah yang umum digunakan dan familiar bagi mitra tutur, seperti: ' $C T F$ online' dan 'kelas Information Security'.

Pada data 21 tujuan penutur mengalih dan mencampur kodekan pernyataannya dengan tag 'nya?' adalah untuk memberikan penekanan pada pernyataan yang diungkapkan sebelumnya.

Pada data 22 tujuan penutur mengalih dan mencampur kodekan pernyataannya adalah untuk menunjukkan hubungan yang informal atau kedekatan. Hal ini bisa dilihat dari penggunaan klausa yang bersifat informal, seperti: 'for all my students do not too lazy'. Terlihat sekali penutur berusaha mendapatkan perhatian mitra tuturnya dengan memperlihatkan kedekatan hubungan dengan mitra tuturnya.
Pada data 24 tujuan penutur mengalih dan mencampur kodekan pernyataannya adalah untuk memperhalus pernyataannya dengan mengakhiri pernyataannya dengan 'Nuhun' yang menyiratkan ungkapan terima kasih.

\section{KESIMPULAN}

Sebagai Universitas yang selalu mengikuti perkembangan jaman UNIKOM berusaha untuk meningkatkan mutu pendidikan salah satunya dengan kuliah online. Kuliah Online adalah media interaktif antara dosen dan mahasiswa melalui media internet. Dengan kuliah online dosen dapat mengunggah materi kuliah atau memberikan informasi yang penting kepada mahasiswa. Mahasiswa juga dapat mengajukan pertanyaan dan mengunduh materi perkuliahan. Pada halaman utama, dosen dapat memberikan pengumuman yang berhubungan dengan perkuliahan sehingga pengumuman dapat diakses dengan lebih cepat tanpa harus masuk lagi ke menu kelas yang dimaksudkan. Dalam memberikan pengumuman dosen terkadang menggunakan alih dan campur kode baik bahasa asing ataupun bahasa daerah. Bentuk dan jenis alih dan campur kode yang digunakan beragam. Jenis alih kode bisa berupa alih kode intra, tag, ataupun antar kalimat/klausa. Sedangkan bentuk alih dan campur kode bisa berupa alih kode interen atau ekstern. Penggunaan alih dan campur kode ini juga memiliki beragam tujuan.

Berdasarkan 44 kasus alih dan campur kode yang terdapat dalam aplikasi kuliah online UNIKOM, kasus alih kode yang paling banyak adalah alih kode intra kalimat sebanyak 38 kasus atau 86,3\%. Sedangkan, alih kode yang paling sedikit terjadi adalah alih kode tag yakni sebanyak 2,3\% atau setara dengan 1 kasus. Jenis alih kode yang lain yang terdapat dalam kuliah online adalah alih kode antar kalimat/klausa. Adapun presentase jenis alih kode ini mencapai $11,4 \%$ atau 
sebanyak 5 kasus. Maka bisa disimpulkan jika pola komunikasi dosen UNIKOM memiliki kecenderungan untuk melakukan alih kode intra kalimat dibandingkan antar kalimat dan tag. Untuk kasus intra kalimat, ada beberapa temuan yang menarik. Pertama, terdapat pembentukan kata yang memadukan dua unsur bahasa yang berbeda yaitu 'didownload' dan 'diupload.' Kata kerja yang digunakan dalam data tersebut merupakan bentukan pasif, namun dibentuk oleh imbuhan ' $d i$-' dalam bahasa Indonesia, dan 'upload' dan 'download' dalam bahasa Inggris. Kasus ini tidak bisa dikategorikan baster karena muncul pada satu kata yang sama; penggunaan kata yang seharusnya tepat untuk digunakan adalah 'diunggah' dan 'diunduh'. Kedua, ditemukannya data yang menggunakan bahasa Inggris tetapi tidak mengikuti pembentukan frasa yang sesuai dengan kaidah bahasa Inggris yakni frasa 'quiz online' pada prinsipnya dibentuk oleh dua kata bahasa Inggris: 'quiz' dan 'online'; akan tetapi pembentukan frasanya adalah DM (Diterangkan - Menerangkan). Kaidah pembentukan frasa dalam bahasa Inggris yang seharusnya adalah MD (Menerangkan-Diterangkan). Maka frasa ini seharusnya 'online quiz.' Jadi, kasus ini merupakan kasus baru terhadap pembentukan baster, yakni dibentuk oleh dua kata dalam bahasa yang sama namun masih mengikuti kaidah pembentukan bahasa sumber.

Adapun bentuk alih dan campur kode yang paling banyak adalah alih kode ekstern sebanyak 39 kasus atau 88,6\%, sedangkan bentuk alih kode interen hanya ditemukan 5 kasus atau 11,4\%. Bentuk alih dan campur kode yang berbentuk interen kebanyakan menggunakan alih kode bahasa Sunda seperti 'nuhun', 'sok atuh', 'nya', hal ini diasumsikan karena subjek penelitian memang berada di kawasan Bandung. Tetapi, ada juga yang menggunakan alih dan campur kode menggunakan bahasa Betawi seperti 'senen' dan 'malem' yang juga merupakan bentuk "colloquial" dari bahasa Indonesia. Disisi lain, alih kode ekstern yang ditemukan sebagian besar menggunakan bahasa Inggris, hal ini dapat terjadi karena bahasa Inggris adalah bahasa Internasional yang familiar atau cukup dipahami oleh penutur dan mitra tutur di aplikasi tersebut. Jika ditinjau dari tujuan penggunaanya, dari total 26 kasus, hanya ada empat tujuan alih dan campur kode yang ditemukan, yakni: memperhalus permintaan sebanyak 3 kasus atau setara $11,6 \%$, memberikan penekanan dari ungkapan sebanyak 1 kasus atau setara $3,8 \%$, menunjukkan hubungan yang informal/kedekatan sebanyak 4 kasus atau setara 15,4\%, dan kebutuhan leksikal sebanyak 18 kasus atau setara 69,2\%. Berdasarkan kasus yang ditemui dalam aplikasi kuliah online UNIKOM, terlihat bahwa banyak dosen yang menggunakan alih dan campur kode disebabkan oleh kebutuhan leksikal. Hal ini terjadi karena tidak adanya padanan kata atau juga untuk memudahkan penutur menyampaikan maksudnya dan memudahkan juga untuk mitra tutur memahaminya.

Penggunaan alih dan campur kode terkadang tidak terhindarkan baik disebabkan oleh kebutuhan leksikal, pengaruh bahasa daerah, atau kebutuhan untuk membuat komunikasi menjadi lebih dekat dan bersifat informal dan berbagai tujuan lainnya. Tetapi perlu juga dipertimbangkan pentingnya untuk menggunakan bahasa Indonesia yang baik dan benar; terlebih jika sudah ada padanan leksikal pada kata tersebut, misalnya kata 'unduh' dan 'unggah' yang jarang digunakan dibandingkan dengan kata 'download' dan 'upload.' Maka diperlukan kesadaran dari pengguna bahasa Indonesia untuk menggunakan padanan Bahasa Indonesia yang juga merupakan upaya pelestarian bahasa.

\section{DAFTAR PUSTAKA}


Chloros, Penelope Gardner. (2009). Code Switching.

Cambridge: Cambridge University Press.

Ohoiwutun, Paul. (2007). Sosiolinguistik: Memahami Bahasa dalam Konteks Masyarakat dan Kebudayaan. Jakarta: Kesaint Blanc.

Rahardi, K. (2001). Sosiolinguistik, Kode dan Alih Kode. Yogyakarta: Pusataka Pelajar.
Romaine, Suzanne. (2004). LanguageContact Studies. Sosiolinguistics: An International Handbook of the Science of Language and Society, 2nd Edition. Berlin: Walter de Gruyter.

Saville-Troike, Muriel. (2003). The Ethnography of Communication: An Introduction 3rd Edition. Oxford: Blackwell Publishing 